\title{
PENGARUH PELATIHAN, DUKUNGAN MANAJEMEN PUNCAK DAN KEJELASAN TUJUAN TERHADAP EFEKTIVITAS SISTEM AKUNTANSI KEUANGAN DAERAH (Studi Empiris Pada Pemerintah Kabupaten Badung)
}

\author{
Cok Istri Ratna Sari Dewi*, Luh Putu Lusi Setyandarini Surya dan Cokorda Krisna Yudha \\ Fakultas Ekonomi dan Bisnis, Universitas Warmadewa, Denpasar-Bali, Indonesia \\ *Email: coknanaa@gmail.com
}

DiPublikasi: 01/01/2020

http://dx.doi.org/10.22225/kr.11.2.1417.110-116

\begin{abstract}
Abstrcat
This study aims to determine the effect of training, top management support and clarity of objectives on the effectiveness of the Regional Financial Accounting System (SAKD) in Regional Implementing Organizations (OPD) in the Government of Badung Regency. A successful implementation of the system is not only determined by mere technical mastery, the behavioral factors of individual system users can also determine the success of implementation. Training factors, top management support and clarity of objectives are needed to increase the effectiveness of the Regional Financial Accounting System (SAKD) in an organization to support the application of the system in meeting the demands of the public regarding transparency and accountability of public sector institutions. This study uses 132 civil servants who have a main duty to manage finances in the OPD at the Badung Regency Government as a research sample. Determination of the sample in this study using simple random sampling technique. The analysis technique used is multiple linear regression analysis. The results of the study found that training, top management support and clarity of objectives on the Regional Implementing Organization (OPD) in the Badung Regency Government had a positive effect on the effectiveness of the Regional Financial Accounting System (SAKD).
\end{abstract}

Keywords: Clarity of purpose; effectiveness of the regional financial accounting system; top management support; training

\begin{abstract}
Abstrak
Penelitian ini bertujuan untuk mengetahui pengaruh pelatihan, dukungan manajemen puncak dan kejelasan tujuan terhadap efektivitas Sistem Akuntansi Keuangan Daerah (SAKD) pada Organisasi Pelaksana Daerah (OPD) di Pemerintah Kabupaten Badung. Suatu keberhasilan implementasi sistem tidak hanya ditentukan pada penguasaan teknis belaka, faktor perilaku dari individu pengguna sistem juga dapat menentukan kesuksesan implementasi. Faktor pelatihan, dukungan manajemen puncak dan kejelasan tujuan diperlukan untuk meningkatkan efektivitas Sistem Akuntansi Keuangan Daerah (SAKD) dalam suatu organisasi untuk mendukung penerapan sistem tersebut dalam memenuhi tuntutan masyarakat tentang transparasi dan akuntabilitas lembaga sektor publik. Penelitian ini menggunakan 132 pegawai negeri sipil yang memiliki tupoksi untuk mengelola keuangan di OPD pada Pemerintah Kabupaten Badung sebagai sampel penelitian. Penentuan sampel dalam penelitian ini menggunakan teknik simple random sampling. Teknik analisis yang digunakan adalah analisis regresi linier berganda. Hasil penelitian menemukan bahwa pelatihan, dukungan manajemen puncak dan kejelasan tujuan pada Organisasi Pelaksana Daerah (OPD) di Pemerintah Kabupaten Badung berpengaruh positif terhadap terhadap efektivitas Sistem Akuntansi Keuangan Daerah (SAKD).
\end{abstract}

Kata Kunci: Kejelasan tujuan; efektivitas sistem akuntansi keuangan daerah; dukungan manajemen puncak; pelatihan

\section{PENDAhUluAN}

Pemerintah daerah dituntut untuk memiliki sistem informasi akuntansi yang handal dan dapat menyediakan informasi keuangan yang diperlukan oleh para pengguna informasi keuangan tersebut secara akurat, relevan, tepat waktu dan reliable. Otonomi daerah merupakan bagian dari demokratisasi dalam menciptakan sistem dimana setiap pemerintahan dituntut untuk mandiri dalam mengelola daerahnya sehingga pengelolaan keuangan sepenuhnya berada ditangan pemerintah daerah. Dengan adanya pelaksanaan otonomi daerah, sistem pengelolaan keuangan daerah diharapkan dapat dikelola dengan transparan, efektif, efisien dan dapat dipertanggungjawabkan pada masyarakat luas (Kayati, 2016). Hal tersebut dapat diwujudkan melalui pengembangan inovasi-inovasi pada sistem informasi akuntansi. Dalam mengelola keuangan suatu daerah diperlukan suatu sistem yang biasa disebut dengan Sistem Akuntansi Keuangan Daerah dan selanjutnya akan disingkat menjadi SAKD. SAKD yang digunakan saat ini 


\begin{abstract}
adalah sistem akuntansi yang mengacu pada kebijakan perundang-undangan yaitu Permendagri No. 13/2006 yang kemudian direvisi pada Permendagri No. 59/2007 dan direvisi kembali pada Permendagri No. 21/2011 tentang Pedoman Pengelolaan Keuangan Daerah. SAKD merupakan serangkaian prosedur mulai dari proses pengumpulan data, pencatatan, pengikhtisaran sampai pelaporan keuangan dalam rangka pertanggungjawaban pelaksanaan Anggaran Pendapatan Belanja Daerah (APBD) yang dapat dilakukan secara manual atau aplikasi komputer. Proses akuntansi tersebut didokumentasikan dalam bentuk buku jurnal besar dan apabila diperlukan ditambah dengan buku besar pembantu, maka hal ini terlihat jelas bahwa sistem akuntansi sangat diperlukan dalam pengelolaan keuangan di daerah. Oleh karena itu penerapan SAKD ini merupakan salah satu syarat dan pedoman bagi pemerintah untuk dapat menghasilkan laporan keuangan daerah yang berkualitas.
\end{abstract}

Pengembangan suatu sistem merupakan suatu proses yang kompleks untuk dilakukan karena memerlukan perencanaan yang matang serta kehati-hatian dalam pengimplementasiannya. Efektivitas pengimplementasian suatu sistem akuntansi berdasarkan kemudahan pengguna dalam mengidentifikasi, mengakses dan menginterpretasikan data patut dipertimbangkan agar sistem tersebut dapat memberikan manfaat yang maksimal. Sebab, data yang disajikan dalam sistem informasi merupakan data yang terintegrasi dari seluruh unit suatu organisasi sehingga dapat digunakan untuk berbagai kebutuhan organisasi tersebut. Implementasi suatu sistem informasi dapat tercapai sesuai tujuan dengan melakukan evaluasi sejauh mana efektivitas sistem informasi tersebut. Suatu keberhasilan implementasi sistem tidak hanya ditentukan pada penguasaan teknis belaka, namun banyak penelitian menunjukkan bahwa faktor perilaku dari individu pengguna sistem sangat menentukan kesuksesan implementasi (Bodnar \& S, 2003). (Latifah \& Sabeni, 2007) menyatakan bahwa agar dapat meningkatkan kegunaan SAKD, maka perlu adanya faktor perilaku dalam suatu organisasi untuk mendukung penerapan sistem tersebut dalam memenuhi tuntutan masyarakat tentang transparasi dan akuntabilitas lembaga sektor publik. Menurut (Robbins, 2003) perilaku organisasi merupakan suatu tindakan yang dilakukan oleh individu atau kelompok dalam organisasi dalam rangka mencapai tujuan organisasi. Penerapan SAKD merupakan bagian dari tujuan pemerintah daerah untuk menghasilkan laporan keuangan pemerintah daerah yang berkualitas dalam rangka pertanggungjawaban pelaksanaan APBD. Faktor keperilakuan organisasi yang digunakan dalam penelitian ini adalah pelatihan, dukungan manajemen puncak serta kejelasan tujuan. Agar sistem informasi akuntansi keuangan daerah dapat terwujud maka ketiga faktor keperilakuan organisasi tersebut harus dipertimbangkan. Hal ini penting untuk diteliti mengingat apabila dalam suatu organisasi pemerintah terdapat kekurangan pelatihan, tidak adanya dukungan manajemen puncak serta tidak adanya kejelasan tujuan yang akhirnya dapat berakibat langsung pada efektivitas SAKD. Penelitian mengenai pengaruh pelatihan, dukungan manajemen puncak dan kejelasan tujuan sudah banyak dilakukan namun menemukan hasil yang tidak konsisten. Mengingat pentingnya peranan SAKD bagi pemerintah daerah dan dengan adanya hasil yang tidak konsisten pada hasil penelitian sebelumnya, penelitian ini bermaksud untuk menguji kembali seberapa jauh pelatihan, dukungan manajemen puncak dan kejelasan tujuan dapat memengaruhi efektivitas SAKD di pemerintah daerah.

Berdasarkan latar belakang diatas, adapun rumusan masalah dalam penelitian ini adalah apakah pelatihan, dukungan manajemen puncak dan kejelasan tujuan berpengaruh terhadap efektivitas sistem akuntansi keuangan daerah. Adapun tujuan yang diharapkan adalah untuk pengaruh pelatihan, dukungan manajemen puncak dan kejelasan tujuan terhadap efektivitas sistem akuntansi keuangan daerah. Penelitian ini dilakukan pada pemerintah Kabupaten Badung. Secara spesifik, penelitian ini diharapkan dapat memberi beberapa kontribusi. Dimana pada nantinya hasil penelitian ini diharapkan dapat memberikan manfaat bagi pihak akademisi dalam menambah literaratur mengenai pengaruh pelatihan, dukungan manajemen puncak dan kejelasan tujuan terhadap efektivitas SAKD maupun pemerintah daerah sebagai bahan pertimbangan dan masukan dalam pengimplementasian SAKD yang transparan dan efektif.

\section{HIPOTESIS}

Menurut Shield (1995) dalam (Mranani \& Lestiorini, 2011) berpendapat bahwa pelatihan dalam desain implementasi dan penggunaan suatu 
inovasi seperti adanya sistem baru memberikan kesempatan bagi organisasi untuk dapat mengartikulasi hubungan antara implementasi sistem baru tersebut dengan tujuan organisasi serta menyediakan suatu sarana bagi pengguna untuk dapat mengerti, menerima dan merasa nyaman dari perasaan tertekan atau perasaan khawatir dalam proses implementasi. Pelatihan merupakan proses keterampilan kerja timbal balik yang bersifat membantu, oleh karena itu dalam pelatihan seharusnya diciptakan suatu lingkungan dimana para karyawan dapat memperoleh atau mempelajari sikap kemampuan, keahlian, pengetahuan dan perilaku yang spesifik yang berkaitan dengan pekerjaan, sehingga dapat mendorong mereka untuk dapat bekerja lebih baik (Zahro, 2012).

Dukungan manajemen puncak dalam suatu pengembangan sistem sangat penting karena adanya kekuasaan manajer terkait dengan sumber daya. Atasan dapat fokus terhadap sumber daya yang diperlukan, tujuan dan inisiatif strategi yang direncanakan apabila atasan mendukung sepenuhnya dalam mewujudkan efektivitas suatu sistem. Dukungan manajemen puncak memiliki pengaruh yang positif terhadap efektivitas sistem akuntansi keuangan daerah sebab apabila di dalam suatu organisasi pemerintahan tidak ada dukungan manajemen puncak maka sistem yang akan dikembangkan tidak akan sesuai dengan rencana organisasi dan menghambat kinerja dari organisasi tersebut.

Kejelasan tujuan dalam organisasi pemerintah dapat terlihat dari visi dan misi organisasi terkait. SAKD merupakan alat yang digunakan oleh pemerintah daerah untuk menghasilkan laporan keuangan yang berkualitas. Kejelasan tujuan dalam suatu organisasi dapat menentukan suatu keberhasilan sistem, karena individu dengan suatu kejelasan tujuan akan lebih dapat memahami bagaimana cara mereka dalam mencapai target untuk mencapai tujuan dengan menggunakan keterampilan dan kompetensi yang dimiliki. (Chenhall, 2004) dalam (Nurlaela \& Rahmawati, 2010) menjelaskan bahwa kejelasan tujuan didefinisikan sebagai kejelasan dari sasaran dan tujuan digunakannya Sistem Akuntansi Keuangan Daerah di semua level organisasi. Sedangkan menurut (Latifah \& Sabeni, 2007) menjelaskan bahwa kejelasan tujuan dapat menentukan suatu keberhasilan sistem karena individu dengan suatu kejelasan tujuan, target yang jelas dan paham bagaimana mencapai tujuan, mereka dapat melaksanakan tugas dengan ketrampilan dan kompetensi yang dimiliki.

Penelitian yang dilakukan oleh (Latifah \& Sabeni, 2007) tentang faktor keprilakuan yaitu pelatihan, dukungan manajemen puncak dan kejelasan tujuan serta adanya konflik kognitif dan afektif yang berpengaruh terhadap implementasi sistem akuntansi keuangan daerah. Responden penelitian ini adalah pegawai Badan Pengelola Keuangan Daerah pada kota Jawa Tengah dan Yogyakarta. Hasil penelitian ini menunjukkan bahwa dari faktor keprilakuan organisasi yang diuji, hanya dukungan atasan yang berpengaruh untuk meningkatkan kegunaan SAKD. Pengaruh pelatihan dan kejelasan tujuan terhadap kegunaan SAKD tidak berhasil dibuktikan. Konflik kognitif tidak berhubungan positif dengan kegunaan SAKD. Konflik afektif berhubungan negatif dengan kegunaan SAKD.

Penelitian yang sama, dilakukan oleh (Nurlaela \& Rahmawati, 2010) pada Pemerintah Daerah Subosukawonosraten. Hasil penelitian menemukan bahwa pengaruh pelatihan dan kejelasan tujuan terhadap kegunaan Sistem Akuntansi Keuangan Daerah tidak berhasil dibuktikan. Konflik kognitif tidak berhubungan positif terhadap kegunaan sistem akuntansi keuangan daerah. Konflik afektif berhubungan negatif terhadap kegunaan sistem akuntansi keuangan daerah. Hanya dukungan atasan yang berpengaruh untuk meningkatkan Kegunaan Sistem Akuntansi Keuangan Daerah. Sedangkan penelitian yang dilakukan oleh (Fatimah, 2013), (Wati \& Batlajery, 2015), (Kayati, 2016) menemukan bahwa faktor pelatihan, dukungan manajemen puncak dan kejelasan tujuan berpengaruh terhadap kegunaan sistem akuntansi keuangan daerah. Berdasarkan paparan hasil penelitian tersebut, maka hipotesis yang dapat disusun adalah:

H1: Pelatihan berpengaruh positif terhadap 
efektivitas sistem akuntansi keuangan daerah.

H2: Dukungan manajemen puncak berpengaruh positif terhadap efektivitas sistem akuntansi keuangan daerah.

H3: Kejelasan tujuan berpengaruh positif terhadap efektivitas sistem akuntansi keuangan daerah.

\section{III.METODE}

Penelitian ini dilakukan pada seluruh Organisasi Perangkat Daerah (OPD) di Pemerintah Kabupaten Badung yang terdiri dari 30 OPD.

Dari jumlah populasi yaitu seluruh pegawai negeri sipil yang memiliki tupoksi untuk mengelola keuangan di OPD pada Pemerintah Kabupaten Badung, sampel dipilih berdasarkan teknik simple random sampling. Pengambilan sampel dalam penelitian ini dihitung menggunakan Rumus Slovin dan mendapatkan jumlah sampel sebanyak 161 responden. Adapun teknik yang digunakan untuk pengumpulan data dalam penelitian ini adalah metode angket (kuesioner). Variabel dependen (Y) pada penelitian ini adalah efektivitas sistem akuntansi keuangan daerah yang diukur dengan skala Likert 1-5. Variabel independen (X) yang terdiri pelatihan (X1), dukungan manajemen puncak (X2) dan kejelasan tujuan (X3) diukur dengan skala Likert 1-5.

Pengujian terhadap instrumen penelitian dilakukan dengan melakukan uji validitas dan reabilitas instrumen, dengan tujuan untuk menguji apakah instrumen dan data penelitian berupa jawaban responden telah dijawab dengan benar atau tidak, sehingga penelitian dapat memperoleh hasil penelitian yang valid dan reliabel. Teknik analisis data yang digunakan dalam penelitian ini adalah teknik analisis regresi linear berganda. Namun sebelumnya akan dilakukan uji asumsi klasik. Uji asumsi klasik bertujuan untuk mengetahui hubungan antara variabel bebas dengan variabel terikat sehingga hasil analisis dapat diinterpretasikan dengan lebih akurat, efisien dan terbebas dari gejala-gejala asumsi klasik. Uji asumsi klasik terdiri dari beberapa pengujian yaitu uji normalitas, uji multikolinearitas dan uji heteroskedastisitas.

\section{IV.HASIL DAN PEMBAHASAN}

\section{Hasil}

Data penelitian ini dikumpulkan dengan menyebarkan kuesioner ke seluruh pegawai negeri sipil yang memiliki tupoksi untuk mengelola keuangan di seluruh OPD pada Pemerintah Kabupaten Badung. Penyebaran kuesioner dilakukan dengan cara mendatangi dan membagikan secara langsung kuesioner kepada masing-masing responden yang akan dijadikan sampel dalam penelitian. Dari 161 kuesioner yang disebarkan, sebanyak 132 kuesioner yang kembali dan layak dianalisis.

Bedasarkan pengujian instrument, hasil uji validitas menunjukkan seluruh nilai koefisien korelasi dari instrumen ini lebih besar dari 0,30 , sehingga instrumen penelitian ini dapat dikatakan valid. Hasil uji reliabilitas dilakukan dengan uji statistik Cronbach Alpha. Suatu variabel dikatakan reliabel atau andal jika nilai Cronbach Alpha lebih besar 0,60 (Ghozali, 2012). Seluruh variabel yang digunakan dalam penelitian ini memiliki nilai koefisien Cronbach Alpha lebih besar dari 0,60 sehingga pernyataan pada kuesioner tersebut reliabel. Sebelum melakukan analisis regresi linear berganda, terlebih dahulu dilakukan pengujian asumsi klasik. Berdasarkan pengujian asumsi klasik diketahui bahwa variabel penelitian berdistribusi normal serta terbebas dari masalah multikolonieritas dan heteroskedastisitas.

Analisis pengaruh pelatihan, dukungan manajemen puncak dan kejelasan tujuan terhadap efektivitas sistem akuntansi keuangan daerah di uji dengan menggunakan analisis regresi liniear berganda. Hasil analisis disajikan pada Tabel 1.

Berdasarkan hasil analisis regresi linear berganda yang ditunjukan pada Tabel 1, maka dapat dibentuk persamaan regresi sebagai berikut.

$$
Y=0,774+0,095 X 1+0,280 X 2+0,819 X 3+
$$
$\boldsymbol{\varepsilon}$

Koefisien persamaan regresi di atas mengindikasikan bahwa variabel pelatihan, dukungan manajemen puncak dan kejelasan tujuan memiliki pengaruh searah dengan variabel terikat yaitu efektivitas Sistem Akuntansi Keuangan Daerah (SAKD). Nilai koefisien regresi variabel variabel pelatihan (X1) sebesar 0,095, dukungan manajemen puncak (X2) sebesar 0,280 dan kejelasan tujuan (X3) sebesar 0,819. Hasil tersebut menunjukkan bahwa variabel pelatihan, dukungan manajemen puncak dan kejelasan tujuan berpengaruh positif terhadap efektivitas Sistem Akuntansi Keuangan Daerah 
(SAKD) di Pemerintah Kabupaten Badung. Selain itu, hasil regresi juga menunjukkan Adjusted $R$ Square sebesar 0,813 yang artinya pelatihan, dukungan manajemen puncak dan kejelasan tujuan terhadap efektivitas Sistem Akuntansi Keuangan Daerah (SAKD) adalah sebesar 81,3 persen, sedangkan sisanya sebesar
18,7 persen dijelaskan oleh variabel-variabel lain diluar model penelitian. Berdasarkan hasil analisis pada Tabel 1, dapat dilihat bahwa nilai signifikansi $\mathrm{F}$ adalah 0,000 atau lebih kecil dari 0,05 sehingga dapat disimpulkan model ini layak digunakan dalam penelitian.

Tabel 1

Hasil Analisis Regresi Linier Berganda

\begin{tabular}{cccc}
\hline Variabel & $\begin{array}{c}\text { Koefisien Re- } \\
\text { gresi }(\boldsymbol{\beta})\end{array}$ & t & Sig. \\
\hline (Constant) & 0,774 & 1,658 & 0,000 \\
Pelatihan (X1) & 0,095 & 3,115 & 0,002 \\
Dukungan Manajemen Puncak (X2) & 0,280 & 2,659 & 0,009 \\
Kejelasan Tujuan (X3) & 0,819 & 6,613 & 0,000 \\
Adjusted R Square & & & 0,813 \\
Signifikansi F & & & 0,000 \\
\hline
\end{tabular}

Sumber: Data diolah (2019)

\section{Pembahasan}

Pengaruh Pelatihan terhadap Efektivitas Sistem Akuntansi Keuangan Daerah

Hipotesis pertama (H1) dalam penelitian ini menyatakan bahwa pelatihan berpengaruh positif terhadap efektivitas sistem akuntansi keuangan daerah. Semakin tinggi tingkat pelatihan maka efektivitas sistem akuntansi keuangan daerah juga akan semakin meningkat. Hasil pengujian hipotesis menunjukkan bahwa pelatihan berpengaruh positif terhadap efektivitas sistem akuntansi keuangan daerah di Pemerintah Kabupaten Badung.

Pelatihan merupakan salah satu faktor penting dalam pengembangan dan pengimplementasian suatu sistem. Pelatihan merupakan proses keterampilan kerja timbal balik yang bersifat membantu, oleh karena itu dalam pelatihan seharusnya diciptakan suatu lingkungan dimana para karyawan dapat memperoleh atau mempelajari sikap kemampuan, keahlian, pengetahuan dan perilaku yang spesifik yang berkaitan dengan pekerjaan, sehingga dapat mendorong mereka untuk dapat bekerja lebih baik (Zahro, 2012). Dengan adanya pelatihan dapat memberikan kemudahan bagi pengguna dalam proses implementasi sistem itu sendiri sehingga efektivitas sistem akan meningkat dan dapat berdampak positif pada kinerja organisasi. Berdasarkan hasil jawaban kuesioner responden yaitu pegawai negeri sipil yang memiliki tupoksi untuk mengelola keuangan di OPD pada Pemerintah Kabupaten Badung, pelatihan yang didapatkan sudah cukup baik. Hasil penelitian ini sejalan dengan hasil penelitian (Fatimah, 2013), Wati dan Semuel (2015) dan (Kayati, 2016) yang menemukan bahwa faktor pelatihan, dukungan manajemen puncak dan kejelasan tujuan berpengaruh terhadap efektivitas sistem akuntansi keuangan daerah. Namun, hasil penelitian ini berbeda dengan hasil penelitian yang dilakukan oleh (Nurlaela \& Rahmawati, 2010) serta (Latifah \& Sabeni, 2007) yang menemukan bahwa pelatihan tidak berpengaruh terhadap efektivitas sistem akuntansi keuangan daerah.

Pengaruh Dukungan Manajemen Puncak terhadap Efektivitas Sistem Akuntansi Keuangan Daerah

Hipotesis kedua $\left(\mathrm{H}_{2}\right)$ dalam penelitian ini menyatakan bahwa dukungan manajemen puncak berpengaruh positif terhadap efektivitas sistem akuntansi keuangan daerah. Semakin tinggi dukungan yang diberikan oleh manajemen puncak kepada bawahannya, maka efektivitas sistem akuntansi keuangan daerah juga akan semakin meningkat. Hasil pengujian hipotesis menunjukkan bahwa dukungan manajemen puncak berpengaruh positif terhadap efektivitas sistem akuntansi keuangan daerah di Pemerintah Kabupaten Badung.

Dukungan manajemen puncak atau atasan dalam suatu pengimplemetasian suatu sistem 
(Studi Empiris Pada Pemerintah Kabupaten Badung)

\begin{abstract}
sangatlah penting. Dengan adanya dukungan penuh dari atasan, perhatian secara menyeluruh dapat diberikan kepada bawahan, tujuan serta strategi yang telah direncanakan sehingga sistem tersebut dapat dijalankan dengan efektif. Manajemen puncak memegang peranan penting dalam setiap tahap siklus pengembangan sistem yang meliputi perencanaan, perancangan, dan implementasi. Apabila di dalam suatu organisasi pemerintahan tidak terdapat dukungan manajemen puncak maka sistem yang akan dikembangkan tidak akan sesuai dengan rencana organisasi dan menghambat kinerja dari organisasi tersebut. Berdasarkan hasil jawaban kuesioner responden yaitu pegawai negeri sipil yang memiliki tupoksi untuk mengelola keuangan di OPD pada Pemerintah Kabupaten Badung, dukungan manajemen puncak yang diperoleh sudah cukup tinggi. Hasil penelitian ini sejalan dengan hasil penelitian (Fatimah, 2013), Wati dan Semuel (2015) dan (Kayati, 2016) yang menemukan bahwa faktor pelatihan, dukungan manajemen puncak dan kejelasan tujuan berpengaruh terhadap efektivitas sistem akuntansi keuangan daerah. Hasil penelitian (Nurlaela \& Rahmawati, 2010) serta (Latifah \& Sabeni, 2007) juga menemukan adanya pengaruh dukungan atasan terhadap efektivitas sistem akuntansi keuangan daerah.
\end{abstract}

\section{Pengaruh Kejelasan Tujuan terhadap Efektivitas} Sistem Akuntansi Keuangan Daerah

Hipotesis ketiga $\left(\mathrm{H}_{3}\right)$ dalam penelitian ini menyatakan bahwa kejelasan tujuan berpengaruh positif terhadap efektivitas sistem akuntansi keuangan daerah. Semakin jelas tujuan yang ditetapkan oleh suatu organisasi, maka efektivitas sistem akuntansi keuangan daerah juga akan semakin meningkat. Hasil pengujian hipotesis menunjukkan bahwa kejelasan tujuan berpengaruh positif terhadap efektivitas sistem akuntansi keuangan daerah di Pemerintah Kabupaten Badung.

Kejelasan tujuan dalam organisasi pemerintah dapat dilihat dalam visi dan misi organisasi terkait. Menurut (Nurdin \& Diana, 2011) kejelasan tujuan adalah transparansi informasi yang terjadi didalam sebuah perusahaan dan berhubungan dengan sasaran yang hendak dicapai demi kelangsungan hidup perusahaan dimasa depan. SAKD merupakan alat yang digunakan oleh pemerintah daerah untuk menghasilkan laporan keuangan yang berkualitas. Kejelasan tujuan dalam suatu organisasi dapat menentukan keberhasilan suatu sistem. Dengan ditetapkannya suatu target, jelasnya tujuan organisasi yang ditetapkan, serta kemampuan dan ketrampilan untuk pencapaian tujuan tersebut, maka seseorang akan lebih mudah bekerja dalam melaksanakan tugas dengan ketrampilan dan kompetensi yang dimiliki. Efektivitas sistem akuntansi keuangan daerah merupakan bagian dari tujuan organisasi pemerintah daerah untuk menghasilkan laporan keuangan pemerintah daerah yang berkualitas. Berdasarkan hasil jawaban kuesioner responden yaitu pegawai negeri sipil yang memiliki tupoksi untuk mengelola keuangan di OPD pada Pemerintah Kabupaten Badung, tujuan yang ditetapkan oleh organisasi sudah cukup tinggi. Hasil penelitian ini sejalan dengan hasil penelitian (Fatimah, 2013), Wati dan Semuel (2015) dan (Kayati, 2016) yang menemukan bahwa faktor pelatihan, dukungan manajemen puncak dan kejelasan tujuan berpengaruh terhadap efektivitas sistem akuntansi keuangan daerah. Namun, hasil penelitian ini berbeda dengan hasil penelitian yang dilakukan oleh (Nurlaela \& Rahmawati, 2010) serta (Latifah \& Sabeni, 2007) yang menemukan bahwa kejelasan tujuan tidak berpengaruh terhadap efektivitas sistem akuntansi keuangan daerah.

\section{SIMPULAN}

Berdasarkan permasalahan penelitian, tujuan, hipotesis dan hasil pembahasan yang telah dipaparkan sebelumnya, maka dapat disimpulkan bahwa pelatihan, dukungan manajemen puncak dan kejelasan tujuan pada Organisasi Pelaksana Daerah (OPD) di Pemerintah Kabupaten Badung berpengaruh positif terhadap terhadap efektivitas Sistem Akuntansi Keuangan Daerah (SAKD). Berdasarkan hasil jawaban responden penelitian, pelatihan dan dukungan manajemen puncak yang diberikan, serta tujuan yang telah ditetapkan pada Organisasi 


\section{Pelaksana Daerah (OPD) di Pemerintah}

Kabupaten Badung sudah cukup baik.

\section{DAFTAR PUSTAKA}

Bodnar, G. H., \& S, H. W. (2003). Sistem Informasi Akuntansi. Jakarta: Indeks.

Chenhall, R. H. (2004). The role of cognitive and affective conflict in early implementation of activity-based cost management. Behavioral Research in Accounting, 16, 19-44. Retrieved from https:// research.monash.edu/en/publications/the-role-ofcognitive-and-affective-conflict-in-earlyimplementat

Fatimah. (2013). Pengaruh Pelatihan, Dukungan Manajemen Puncak, Dan Kejelasan Tujuan Terhadap Efektivitas Sistem Informasi Akuntansi Keuangan Daerah (Studi Empiris Pada DPKAD Kota Di Sumatera Barat). Jurnal Akuntansi, 1(1). Retrieved from http:// ejournal.unp.ac.id/students/index.php/akt/article/ view/96

Ghozali, I. (2012). Aplikasi Analisis Multivariate dengan Program SPSS. Semarang: Badan Penerbit Universitas Diponegoro.

Kayati. (2016). Pengaruh Faktor Keperilakuan Organisasi Terhadap Kegunaan Sistem Akuntansi Keuangan Daerah. Universitas Negri Semarang. Retrieved from http://ib.unnes.ac.id/23341/1/7211411076.pdf

Latifah, L., \& Sabeni, A. (2007). Faktor Keprilakuan Organisasi Dalam Implementasi Sistem Akuntansi Keuangan Daerah (Simposium Nasional Akuntansi 10). Makasar.

Mranani, M., \& Lestiorini, B. (2011). Faktor Keperilakuan Organisasi Terhadap Kegunaan Sistem Akuntansi Keuangan Daerah Dengan Konflik Kognitif Dan Konflik Afektif Sebagai Intervening. Fokus Ekonomi (FE), 10(3), 193-203. Retrieved from https:// media.neliti.com/media/publications/24465-ID-

faktor-keperilakuan-organisasi-terhadap-kegunaansistem-akuntansi-keuangan-daera.pdf

Nurdin, \& Diana. (2011). Pengaruh Faktor Keperilakuan Organisasi terhadap Sistem Akuntansi Keuangan Daerah. Universitas Bung Hatta.

Nurlaela, S., \& Rahmawati. (2010). Pengaruh Faktor Keperilakuan Organisasi Terhadap Kegunaan Sistem Akuntansi Keuangan Daerah Di Subosukawonosraten. Simposium Nasional Akuntansi XIII Purwokerto. Retrieved from www.sna13purwokerto.com

Peraturan Mentri Dalam Negeri Nomor 13 Tahun 2006 tentang Pedoman Pengelolaan Keuangan Daerah.

Robbins, P. S. (2003). Perilaku Organisasi. Jakarta: PT Indeks.

Wati, C. H. S., \& Batlajery, S. (2015). Faktor Keperilakuan Organisasi Terhadap Kegunaan Sistem Akuntansi Keuangan Daerah Dengan Konflik Kognitif Sebagai Variabel Intervening Di Kabupaten Merauke. Jurnal Ilmu Ekonomi \& Sosial, 6(1). Retrieved from https:// ejournal.unmus.ac.id/index.php/ekosos/article/ view/86 